\title{
Alergia a budesonido intranasal: Um suspeito incomum
}

Allergy to intranasal budesonide: An unusual suspect

Rev Port Imunoalergologia 20I9;27 (3): 247-248

Maria Luís Marques', Álvaro Machado², Inês Lobo²

I Serviço de Imunoalergologia, Centro Hospitalar e Universitário do Porto

${ }^{2}$ Serviço de Dermatologia, Centro Hospitalar e Universitário do Porto
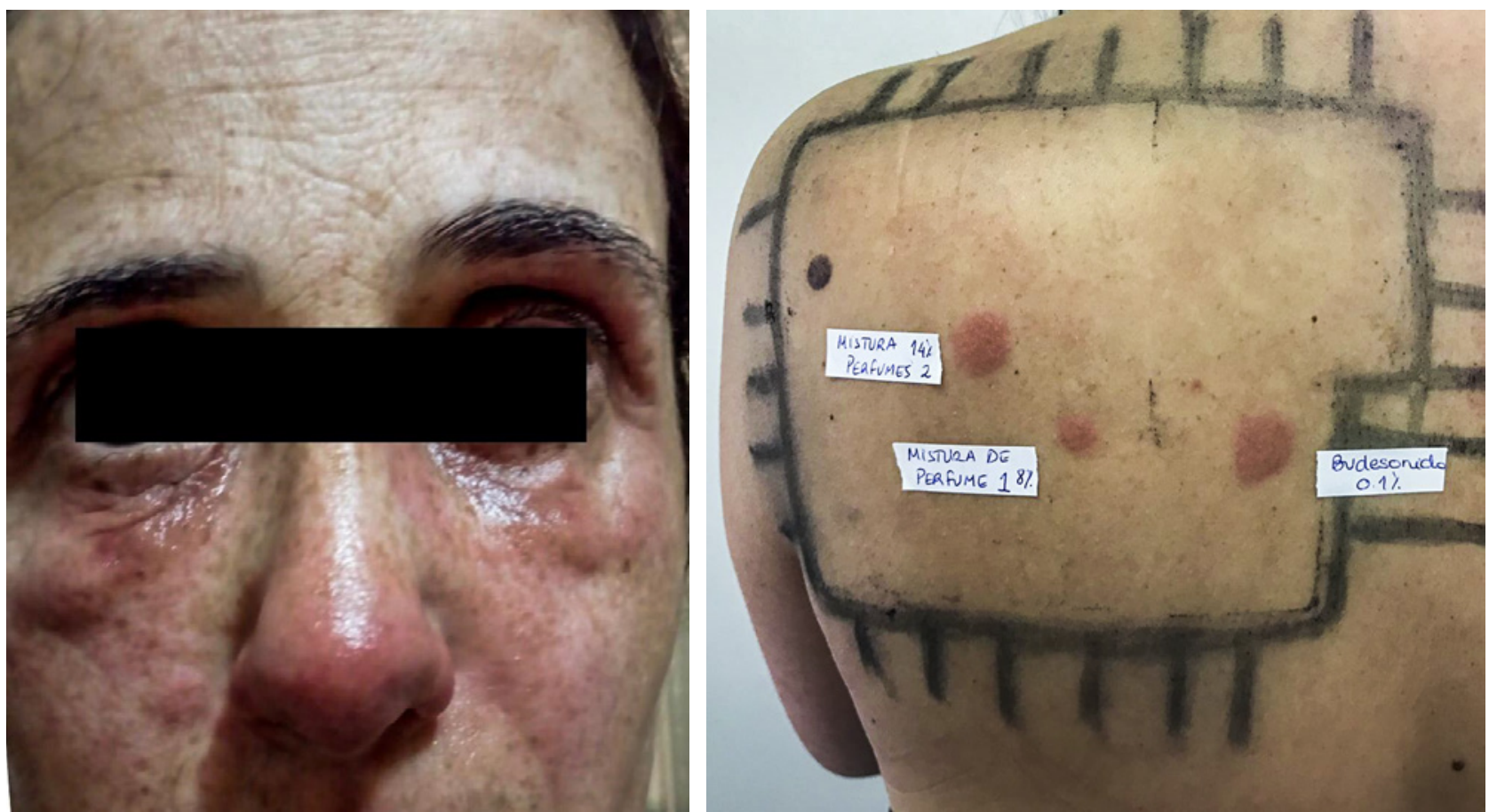

Figura I.

Figura 2. 


\section{COMENTÁRIO}

M ulher de 47 anos com história de rinite alérgica aos ácaros do pó da casa, medicada inicialmente com corticoide intranasal (CIN), fluticasona $50 \mathrm{ug} / \mathrm{ml}$, e desde $2017 \mathrm{com}$ budesonido $100 \mathrm{ug} / \mathrm{ml}, 2$ aplicações/dia e bilastina $20 \mathrm{mg}$ em SOS. Recorre ao serviço de urgência em novembro de 2018 por quadro com duas semanas de evolução de edema e eritema das regiões perinasal e palpebral (Fig. I), com lesões papulares na região cervical, associados a prurido. Realização de testes epicutâneos com a série básica portuguesa e série de medicamentos corticoides tópicos que foram positivos às 72 horas para budesonido (+++) e mistura de perfumes I $(8 \%)(+++)$ e $2(14 \%)(+++)$ na série básica, sem positividade para os restantes corticoides (Fig. 2). Resolução do quadro com suspensão de budesonido intranasal.

As guidelines atuais reconhecem que os $\mathrm{CIN}$ são a terapêutica mais eficaz no controlo sintomático da rinite alérgica' e, apesar de raras e ainda não completamente esclarecidas, estão descritas reações de hipersensibilidade aos corticoides mediadas por lgE e por células $T^{2,3}$. O diagnóstico de hipersensibilidade aos corticoides requer um elevado índice de suspeição e, nas reações tardias, o complemento com os testes epicutâneos permite a identificação do agente responsável e a escolha de um fármaco alternativo.

\section{COMMENT}

Dorty seven year-old woman with house dust mite allergic rhinitis initially treated with intra nasal corticosteroid (INC), fluticasone 50ug/ml, and since 2017 with budesonide $100 \mathrm{ug} / \mathrm{ml} 2$ applications/day and bilastine $20 \mathrm{mg}$ SOS. She went to the Emergency Department in November 2018 for edema and erythema of the perinasal and palpebral regions (Fig. I), and papular lesions in the cervical region, associated with pruritus with two weeks of evolution. Epicutaneous tests with the Portuguese baseline series and topical corticosteroid drugs series were positive at 72 hours for budesonide (+++) and perfume mixture I (8\%) (+++) and $2(14 \%)(+++)$, without positivity for the remaining corticosteroids (Fig. 2). Resolution of the skin lesions with withdrawal of intra nasal budesonide.

Current guidelines recognize that INC are the most effective medication for symptomatic control of allergic rhinitis ${ }^{1}$ and, although rare and not yet fully understood, IgE and T-cell mediated hypersensitivity reactions are described ${ }^{2,3}$. Diagnosis of hypersensitivity to corticosteroids requires a high suspicion index and, in late reactions, accompanied by epicutaneous tests allows the identification of the responsible agent as well as the choice of an alternative drug.

Contacto:

Maria Luís Marques

Serviço de Imunoalergologia,

Centro Hospitalar e Universitário do Porto

Email: maluis234@gmail.com

\section{REFERÊNCIAS}

I. Brozek JL, Bousquet J, Agache I, Agarwal A, Bachert C, Bosnic-Anticevich $S$, et al. Allergic rhinitis and its impact on asthma (ARIA) Guidelines - 2016 Revision. J Allergy Clin Immunol 2017;140:950-8.

2. Lopez S, Torres MJ, Antunez C, et al. Specific immunological response tobudesonide in a patient with delayed-type hypersensitivity reaction. J Invest Dermatol 2010;130:895-7.

3. Torres MJ, Canto G. Hypersensitivity reactions to corticosteroids. Curr Opin Allergy Clin Immunol. 2010;10:273-9. 